\title{
INDEX
}

Note: numbers in bold refer to authorship of chapters; 'n.' after a page reference indicates a note number on that page. Subentries are listed in chronological order.

Alan of Tewkesbury 6, 9, 37; $27, \mathbf{3 8}$

Albert of San Lorenzo, cardinal 216, $244-5$

Alexander Llewelyn the Welshman, Thomas's crossbearer 106, 211

Alexander III, pope 2, 20-3, 25-8, 66, 72-4, 85n.40, 86, 96, 114, 127-34, 138-9, 147, 154, 166, $171-4,177,181,216-17,211$, 222-3, 236, 241

appeals to 25

by Roger of York against

Thomas (1163) 107

by Thomas against the

English bishops (1164) 110, 112-13

by the English bishops

against Thomas (1164) 113

by the English clergy against

Thomas (1166) 35-6, 146-7, 223-4, 237

renewed (1167) 152-4

by Gilbert and Jocelin against

Thomas (1169) 164

by Thomas against the

English bishops (1170) 172 papal missions

of Philip (1163) 86-9

of William and Otto (1167)

25-6, 150-3, 166

of Simon, Bernard and

Englebert (1168) 26, 154

of Gratian and Vivian (1169)

26, 164, 166-9

of Rotrou, Bernard and

William of Pavia (1170) 27, 172 of Albert and Theodwin

(1171) 216, 244-5

of Hugh (1175-76) 216n.72

Amboise, Thomas and Henry meet at (1170) 178-80

Angers, Henry interviews Thomas's clerks at (1166) 142-3

Anno, St 238

Anselm, archbishop of Canterbury 20, 72n.9, 109, 118, 125n.20, 176

Ansketil, prior of Leicester 58

Arnulf, bishop of Lisieux 48, 85

Arnulf, bishop of Séez 112-13

Augustine of Canterbury, St 175 , 234

Avice of Stafford 54

Avranches, settlement at (1172) 34, 216-17, 244-5

Bartholomew, bishop of Exeter 62-3, 120,128, 130, 146, 211,229

Benedict, St 201

Benedict of Peterborough 4, 8, 32; 52,54

Benet of St Albans 11

Bernard, bishop of Nevers 172, 174

Bernard de la Coudre, prior of

Grandmont 26-7, 154

bishops of England

at the Council of Westminster

(1163) 80-2

at the Council of Clarendon

(1164) 88-90, 99, 228-9

at the Council of Northampton

(1164) 102-7, 109n.124, 110,

112-14 
coronation of the young king (1170) 173

Caesarius of Heisterbach 38; 61 Canterbury, Christ Church, monastic community of 4,8 , 32, 62-3, 146, 200, 202, 204-5, 207, 217, 226

Canterbury, St Augustine's abbey 194

Canterbury, St Dunstan's 217

Cistercian order 124, 148-9

Clairmarais, monastery of 124-5

Clarendon, constitutions of 17, 1920, 90-6, 99, 113-14, 132-3, $144,216,239-40$

Clarendon, Council of (1164) 17, 87-91, 97, 106, 110, 113-14, 228-9, 232

Conan IV, duke of Brittany 236n.56

Constance, countess of Toulouse, sister of Louis VII 57

criminous clerks $3,16-17,19,75-$ 80, 93, 239-40

customs of the realm 3, 17, 19, 26, $34,36,82-96,110,113-14$, $132-3,143-4,151-2,155-7$, 159, 169-7o, 216n.72, 228, 233

de Broc family 29, 187, 193, 195, 206 see also John de Broc; Ranulf de Broc; Robert de Broc; Roger de Broc

Denis, St 169, 202

Edmund Rich, archbishop of Canterbury 136

Edward Grim 5, 7, 9-10; 1, 11, 22, $30,35,51,58$

Edward the Confessor, translation of (1163) 16, 74-5, 79n.25, 105n.109

Eleanor of Aquitaine, queen of England 21, 217

Elphege, St 109, 192n.23, 199, 202n.44

Engelram of Trie 58
Englebert, prior of Val-St-Pierre 26, 154

Enjuger de Bohun 192

Eudo, count of Boulogne 192

Eugenius, pope 167

Frederick I Barbarossa, Roman emperor 22, 139, 144, 150

Fréteval, settlement at (1170) 27, $174-7,215,241$

Garnier of Pont-Ste-Maxence 5, 9; 6,46

Geoffrey, count of Anjou, father of Henry II 12, 21, 112-13, $144 n .75$

Geoffrey, duke of Britanny, son of Henry II 217, 236n.56

Geoffrey Ridel 47n.20

Gerard, barefoot monk 139

Gervase of Cornhill, sheriff of Kent 183-5

Gilbert Becket, father of Thomas 11, 40, 41n.6

Gilbert Foliot, bishop of London 2, 4, $8,14,17,22,24,26-8,35-9$, $61,63-5,85,103,106,120$, 128-30, 146-8, 164-6, 173, 181-2, 185, 188-90, 218-19; 59,60

Gisors and Trie, conference between (November 1167) 25-6, 151-2

Gratian, papal notary 26, 164, 166-9 Gregory I, pope 107, 136, 165n.29, 242

Gregory VII, pope 3

Gunter of Winchester, Thomas's clerk 211

Henry I, king of England 3, 19, 47, $74,90,91$

Henry II, king of England accession and early rule $12-13$, $47-8,227,239$

ecclesiastical policy 18-19, 51-2, 76 
friendship with Thomas 52-3, $74-5$

promotes Thomas 59-63

at the Council of Westminster

(1163) 79-80, 82

insists on recognition of his

customs $17,83-5,87$

at the Council of Northampton

(1164) 100-15, 231-2

reaction to Thomas's flight 21-2, 118,120

mission to Louis and Alexander

(1164) 120, 124-32, 135

measures against Thomas (1164)

23, 135-6, 170, 241

interviews Thomas's clerks

(1166) 142-4

removes Thomas from Pontigny

(1166) 148-9

at Montmirail (1169) 154-7, 235

discussions with Gratian and

Vivian 166-8

at Montmartre (1169) 26-7,

169-72

has his son crowned (1170) 172-4 at Fréteval (1170) 27, 174-7

restores Canterbury possessions

177-8, 217

Christmas court at Bur-le-Roi

(1170) 30, 188-9, 191-2, 242 responsibility for murder 33-4,

212, 214, 217-18, 243-5

response to Thomas's death 33 ,

211-14, 216, 244

at Avranches (1172) 34, 216-17,

244-5

rebellion against (1173-74) 217-

19, 244

penance at Thomas's tomb

(1174) 34, 217-18, 245

Henry (III), the young king 29, 51 , $55,62-3,66,72-3,185-7$,

192, 197, 211, 217

coronation of (1170) 27, 172-5, 241

Henry IV, Roman emperor 3

Henry of Blois, bishop of
Winchester 48, 63, 65-6, 103, 104, 117-8, 146-7, 229

Henry of Essex, constable 57

Henry of Pisa, cardinal legate 61

Henry the Lion, duke of Saxony 139

Herbert of Bosham 4, 8, 10, 107, $115,143,157,193-4 ; \mathbf{9}, \mathbf{1 2}$, $15,21,26,29,31,33,36,37$, $40,44,49$

Hilary, bishop of Chichester 2, 17, 22, 62-3, 85-6, 99, 104-5, $113,114,120,128-30,229$

Hostes of St-Omer, Templar 89-90

Hugh de Gundeville, guardian of the young king 192

Hugh de Morville 92, 190-1, 198n.33, 203, 211

see also murderers

Hugh de Nonant, archdeacon of Lisieux 106

Hugh de St Clair 144

Hugh of Horsea ('Mauclerk') 200, 203

see also murderers

Hugh of Pierleone, cardinal 216 n.72 Hugh the clerk 179

Icelandic Saga 5n.3, 11; 2

Investiture contest 3, 20

Ireland, Henry's campaign in 8, 334, 216

Jocelin de Balliol 144

Jocelin de Bohun, bishop of

Salisbury 23, 27-8, 88-90,

$144,146,154,164,173,181-2$,

185, 188-90, 223n.12, 229

Jocelin of Arundel, envoy of the

young king 186

John count of Vendôme 86-7

John de Broc 187

see also de Broc family

John FitzGilbert the Marshal 18,

100-3, 111-12, 114, 230

John of Canterbury, bishop of

Poitiers 162

John of Crema 234 
John of Oxford, dean of Salisbury

27, 139, 144, 150, 154, 180, 223n. 12

John of Salisbury, 4, 7-9, 29, 46n.18, 136, 142-3, 147, 166, 198n.33, 200n.39; 5, 14

John Planeta, the Cantor 107

Jordan Taison 144

kiss of peace $27,170-2,174,177-$ 81

Lambeth Anonymous (Anonymous

II) 5 n.2, $8 ; \mathbf{1 0 ,} \mathbf{5 5}$

Lanfranc, archbishop of Canterbury 109

Lansdowne Anonymous

(Anonymous III) 10; 56, 57

letter collections 1, 8, 9, 35

Louis VII, king of France 2, 6, 20-3, 26, 28, 55-8, 120, 142, 148, 154-5, 157-64, 166, 168-75, $178,180,211,213,217,234$, 240-1

Margaret, wife of Henry the young king 55, 174

Martin of Tours, St 207-8

Matilda, daughter of Henry II 139

Matilda 'the Empress', mother of Henry II 12, 47, 139, 147

Matilda (or Roheise?), mother of Thomas 11, 40-1, 44

Matthew, count of Boulogne 124, 182

Merton, Augustinian priory of 42, 52

Milo, dean of Boulougne 182

Montmartre, Council of (1169) 26-7, 166, 169-72

Montmirail, conference at (1169) 26, 154-62, 166

murderers 30-4, 190-1, 194-204, $211,214-15,242-5$

see also Hugh de Morville; Hugh of Horsea; Reginald FitzUrse; Richard le Bret; William de Tracy
Nigel, bishop of Ely 229

Nigel de Sackvill, keeper of the royal seal 178-9

Northampton, Council of (1164) 18, 57n.47, 95n.74, 100-15, 223, 231-2, 240

Northampton, meeting between Thomas and Henry at (1163) $17,83-5$

Odo, bishop of Bayeux 112

Odo, prior of Canterbury 213

Osbern, Thomas's chamberlain 11718

Osbert Huitdeniers, London financier 12,45

Otto, cardinal 25-6, 150-3

papal schism 22, 66, 72-4, 85n.40, $86,131,139,150,154,166$, 222-3

Paschal III, antipope 139

Peter Lombard 136, 137n.53

Peter the Chanter, master 38, 238

Philip, abbot of Aumône 86-8

Philip, bishop of Bayeux 47-8

Philip II Augustus, king of France 168, 234

Philip de Broi 16, 77-8

Philip of Alsace, count of Flanders $73,120,124,219$

Philip of Calne, Thomas's clerk 142 primacy dispute $79,175-6$

\section{Quadrilogus 11}

Rainald, archbishop of Cologne 139 Ralf of Diss (Diceto) 107

Ralph, prior of Holy Trinity, Aldgate, Thomas's confessor 51

Ranulf de Broc 135, 144, 164, 183-5, 186, 190, 193, 204

see also de Broc family

Reading abbey, dedication of (1164) 16,74

Reginald, earl of Cornwall 89 
Reginald FitzUrse 30-1, 190, 196, 198, 200n.39, 202n.45 see also murderers

Reginald of Warenne, royal justiciar 178-9, 183-5

Rheims, Council of (1148) 12, 46

Rhys of Deheubarth 59n.57

Richard de Haliwell, priest 178

Richard de Lucy, royal justiciar 623, 124n.18, 144, 226

Richard le Bret 30-1, 190-1, 203 see also murderers

Richard of Ambly 50

Richard of Chester 229

Richard of Dover, archbishop of Canterbury 245

Richard of Hastings, master of the Templars 89-90

Richard of Ilchester, archdeacon of Poitiers 144

Richard I, son of Henry II 217

Richer of Laigle 43-4

Robert, canon of Merton 50, 200n.39

Robert, earl of Gloucester 12

Robert, earl of Leicester 89, 114, 192

Robert de Broc 187, 193

see also de Broc family

Robert de Cave, lay brother 117

Robert de Chesney, bishop of

Lincoln 85, 113-14, 229

Robert of Cricklade 5n.3, 11

Robert of Melun, bishop of Hereford 52, 86-7, 108-9, 147, 223, 229

Roger, bishop of Worcester 88-9, 120, 128, 174, 229

Roger, master 38, 238

Roger de Broc 164

see also de Broc family

Roger de Humet 192

Roger of Bray, Thomas's servant

117

Roger of Clare, earl of Hereford 71 'Roger of Pontigny' (Anonymous I) 4, 7, 9-10; 3, 16, 17, 24, 41

Roger of Pont-l'Evêque, archbishop of York 2, 12, 17, 27, 35, 467, 72n.9, 79, 85, 106-7, 120, 128, 130, 173, 181-2, 185, 188-90, 239, 241-2

Rotrou de Beaumont, bishop of Rouen 27, 146-7, 172, 174, 177,180

Saher de Quincy 192

St Bertin's at St-Omer, monastery of 124-6

St Columba's abbey, Sens 23, 148-9

Santiago de Compostela 210

Scaiman, lay brother 117

Sempringham, order of 121

Sens, discussions with the pope at (1164) 22, 127-34

Simon, prior of Mont-Dieu 154

Simon FitzPeter 77

Southwark, canons of 178-9, 185-6

Stephen, king of England 3, 12, 19, 42, 46n.18, 49, 239

Stephen Langton, archbishop of Canterbury 136

Stigand, archbishop of Canterbury 112

Summa causae inter regem et Thomam $10 ; 18$

Theobald, archbishop of Canterbury $12,14,45-8,58-9,62,68,71$, 125n.20, 225-6, 239

Theobald, count of Blois 211

Theodwin of San Vitale, cardinal 216, 244-5

Thomas, presbyter of St Martin's, Canterbury, Thomas's confessor 51

Thomas Becket, archbishop of Canterbury character 42-3, 50, 54-5, 238 physical characteristics 42-3, 11 n. 126, 123, 238

early years $11-15,1-47$ omens at birth $11,40-1$ youth $11,42-4$ education 11-12, 42, 44, 46 
clerk of Archbishop Theobald

$$
\text { 12, 45-7, 238-9 }
$$

chancellor 13-14, 48-5, 55-1, 239 embassy to Paris (1158) 13, 55-6

military campaigns 13, 57-9 familiarity with Henry II 13, $52-3$

promotion to Canterbury (1163)

14, 35, 58-69, 97, 133, 221, 225-7, 239

considers promotion 58-61

election $61-4,226-7$

consecration 65-6

prognostic 66n.81, 191n.19, 227

change of life 14-15, 61, 64, 66-7, 239

life as archbishop 67-9

dispute with the king 2-3, 15-

20, 70-115

initial concord $72-5$

reclaims Canterbury lands 16, $70-2$

excommunicates William of

Eynesford (1163) 78-9,

$94 n .68$

at the Council of Westminster

(1163) 80-3

interview with Henry at

Northampton (1163) 17,

83-5

at the Council of Clarendon

(1164) 87-91, 229

attempts to flee England

(1164) 18, 93n.66, 99-100, 230

at the Council of

Northampton (1164) 100-

15,231

exile 20-8, 116-82

flight 20-2, 93n.66, 116-28,

159, 220, 232, 240

resigns office to pope 22 ,

133-4, 239

Pontigny, stay at 22-3, 134, $136-42,220$ appointed papal legate 23, 139

sends letters of mounting

severity 23-4, 139, 220-1

removed from Pontigny 147-

9

Sens, stay at 132-4, 163

excommunications and suspensions 25

Vézelay (1166) 23, 35, 144-5, 220

Clairvaux and Ascension Day (1169) 153-4, 164-6

renewed (1169) 166, 172

of the bishops involved in the coronation (1170) 28, 1814, 196-7, 201, 241-2

Christmas (1170) 30, 193, 197,201

negotiations

between Gisors and Trie (1167) 151-2

at Montmirail (1169) 154-62

at Montmartre (1169) 26-7, 169-72

at Fréteval (1170) 27, 174-7

return to England 29, 241, 17887

prepares for return 178, 180

reception in England 29, 183-6

attempts to visit the young king 185-6

threatened by the de Broc family $186-7$

portents of death 178-9, 182, 186-7

prepares for death $187,191-4$

murder 28-32, 195-203, 243

plot 189-92, 194-5

interview with the murderers 196-8

ushered into the cathedral 199-200

confronts the murderers 201-2 death 202-3

plunder of the palace 203-4

appearance of body 204

burial 205 
cult $32-3,38$

blood of St Thomas 204-6, 209-10

miracles 204-10, 212, 238, 243

miracle collections 8, 32-3, 206-7

pilgrimage to Canterbury 206-7, 209-10

canonisation (1173) 217

Thomas FitzBernard 144

Toulouse campaign (1159) 13, 57, 103, 226, 227

Tours, papal council of (1163) 16, $72-4$

two swords 75,227

Urban, abbot of Cercamp 139

Vexin campaign (1161) 58-9

Victor IV, antipope 22

Vivian, archdeacon of Orvieto 26, 164, 166-9

Walter, bishop of Rochester 62-3, 65-6, 102, 146, 185

Welsh, attacks by 59

Westminster, Council of (1163) 17, 75n.17, 79-83, 155-6, 160, 228

William, abbot of Ramsey 52

William, earl of Gloucester 103

William d'Aubigny, earl of Arundel 130

William de Courcy, seneschal of Normandy 100-1
William de Mandeville, earl of Essex 192

William de Tracy 30-1, 190-1, 202, 214

see also murderers

William I the Conqueror, king of England 71, 112, 175-6

William II Rufus, king of England 21

William FitzHerbert, archbishop of York 46

William FitzJohn, guardian of the young king, 192

William Fitzstephen 200n.39; 4, 7, $8-9,17,23,28,32,39,42$, $45,48,50,53$

William of Canterbury 4, 8, 200n.39; $25,34,43,47,54$

William of Eynsford 16, 78-9, 94, 103

William of Newburgh 39, 62

William of Pavia, cardinal 25-6, 61n.60, 150-3, 172

William of Ros 71

William of the White Hands, archbishop of Sens 157, 162, 194, 211,215

William of Ypres 49

William the Lion, king of Scotland 214, 217,219

Winchester, bishop of 186

Woodstock, Council of (1163) 16, 76-7

Woodstock (or Oxford?), meeting of Thomas and Henry at (1163) 87,228

Würtzburg, Diet of (1165) 139 